\title{
Utilization of seston flux over a mussel bed
}

\author{
D. K. Muschenheim ${ }^{1}$, C. R. Newell ${ }^{2}$ \\ ${ }^{1}$ Habitat Ecology Division, Biological Sciences Branch, Department of Fisheries and Oceans, Bediord Institute of \\ Oceanography, PO Box 1006, Dartmouth, Nova Scotia, Canada B2Y 4A2 \\ ${ }^{2}$ Great Eastern Mussel Farms, Inc., PO Box 141, Tenants Harbor, Maine 04860, USA
}

\begin{abstract}
A combined sampling approach was used to address the topic of utilization of the nearbed seston field over a natural bed of the blue mussel Mytilus edulis. Samples taken by a new device, the Benthic Organic Seston Sampler (BOSS), were combined with near-bed current information and in situ clearance rate measurements to assess the effect which the Mytilus bed had on the horizontal seston flux. During mid ebb-tide the mussels were capable of processing the flow within $7 \mathrm{~cm}$ of the seabed, but only utilized about $20 \%$ of the seston flux available within that region. The possibility that significant refiltration occurs suggests that the actual effective 'feeding zone' of the mussels was on the order of $3.5 \mathrm{~cm}$. Chlorophyll and carbon analyses and direct cell counts indicated that the mussels fed preferentially on high concentrations of resuspended benthic diatoms, depleting the bottom 3 to $5 \mathrm{~cm}$ of this rich food resource.
\end{abstract}

\section{INTRODUCTION}

The growth of dense bivalve populations is not a simple function of ambient seston concentration or flow velocity, but rather a function of the combined effects of these 2 factors, i.e. the seston flux (Muschenheim 1987a, Cahalan et al. 1989). Although individual suspension feeders most likely respond to the instantaneous ambient seston concentration, the food supply to the population is a function of larger-scale features of the particulate and flow environments (Cahalan et al. 1989). Therefore, the processes which govern the flux of seston to beds of the blue mussel Mytilus edulis are likely to determine the growth of the bed. Recent work has demonstrated the ability of dense aggregations of mussels to deplete the near-bed environment of organic food particles (Wildish \& Kristmanson 1979, Frechette \& Bourget 1985a, b, Newell \& Shumway 1988). Food depletion in dense beds with relatively low seston fluxes was seen by Frechette \& Bourget (1985b), who suggested that this depletion resulted in growth inhibition of the population. Further evidence is supplied by Newell's (1990) observation in continuous mussel patches of 2 to $10 \mathrm{~m}$ in diameter that significantly faster growth occurred at patch edges.
Since gradients in seston concentration (Nowell \& Jumars 1984), composition and flux (Muschenheim $1987 a, b)$ exist near the bed, the vertical range of a suspension-feeder's effective 'feeding zone' (sensu Grizzle \& Lutz 1989, Grizzle \& Morin 1989) will determine the extent to which the organism may take advantage of the local flux regime. Grizzle \& Lutz (1989) found that intermediate seston flux rates produced the highest growth rates in Mercenaria mercenaria when sand sediments were present. This is most likely due to the presence of significant amounts of sand grains in suspension at higher flow rates, causing a reduction in the overall organic composition of the seston.

To further study patterns of seston availability and in an attempt to estimate the effective feeding zone of a continuous mussel bed we conducted a field sampling experiment over a mussel bed in Frenchman's Bay, near Bar Harbor, Maine, USA.

\section{METHODS}

A large, continuous mussel bed in a $3 \mathrm{~m}$ deep tidal channel was chosen for this experiment and was sampled on the ebb tide. The patch was approximately 
$22 \mathrm{~m}$ long and consisted of mussels with a mean shell length of $54.6 \mathrm{~mm}(\mathrm{SD}=11.6, \mathrm{n}=95)$ and biomass of $1402 \mathrm{~g}$ dry tissue weight $\mathrm{m}^{-2}$. Population shell length distribution was bimodal, with peaks in the 45 to $50 \mathrm{~mm}$ range and 60 to $70 \mathrm{~mm}$ range. The mode of the biomass was at 60 to $70 \mathrm{~mm}$. Current flow through the study area on the ebb tide was strongly unidirectional at $9.8 \mathrm{~cm} \mathrm{~s}^{-1}$ measured with a S4 electromagnetic current meter $50 \mathrm{~cm}$ off the bed during the sampling period. Current direction, water depth, temperature and salinity also were monitored continuously. Water temperature was $13^{\circ} \mathrm{C}$, and salinity was $33 \mathrm{ppt}$ while water depth varied from 3.2 to $2.9 \mathrm{~m}$ during the course of sampling.

Mussel feeding experiments were performed, using the technique of Frechette \& Bourget (1985a), during the seston sampling, using seawater pumped from $1 \mathrm{~m}$ off the bottom, in a flow-through chamber $(n=4)$. Mussels were obtained by divers and allowed $1 \mathrm{~h}$ to acclimate before sampling. Flow rates varied from 26.3 to $29.5 \mathrm{l} \mathrm{h}^{-1}$, and mussel mean shell length in the chamber was $69.7 \mathrm{~mm}$ with a mean dry tissue weight of $1.51 \mathrm{~g}$. Duplicate samples for chlorophyll a (chl a) fluorescence (Phinney \& Yentsch 1985) were taken every 6 min from the experimental and control chambers for 5 sampling periods (every $7 \mathrm{~min}$ ). Chl a consumption was calculated as:

$$
C=f\left(Q_{b}-Q_{m}\right)
$$

where $f=$ flow rate; $Q_{\mathrm{b}}=\mathrm{chl}$ a concentration in the outflow of the control chamber; $Q_{\mathrm{m}}=$ chl a concentration in the outflow of the mussel chamber. The filtration rate was estimated from the consumption rate using the method of Frechette \& Bourget (1985a). Filtration rate varied between 7 and $12 \mathrm{l} \mathrm{h}^{-1} \mathrm{~g}^{-1}$. Predicted filtration rates of the mussel bed from the results in the chambers were based on the allometric relationship between dry tissue weight and filtration rate using a weight exponent of 0.72 (Riisgård \& Møhlenberg 1979). Differences between bed filtration rates and those estimated in chambers previously (Frechette et al. 1989) have been negligible and were omitted from these calculations.

Boundary-layer velocity profiles were calculated from the $50 \mathrm{~cm}$ S4 current measurements. The turbulence regime and boundary-layer structure of the flow was assessed through calculation of the roughness Reynolds number Re. which yielded a value of 8.4 . This is in the transitional flow regime; therefore no appreciable presence of a viscous sublayer was expected. A series of laboratory flume experiments (Geyer \& Newell unpubl.) with detailed laser doppler velocity profiles made in 3 cross-stream axes at 7 locations over a $2 \mathrm{~m}$ continuous mussel bed $(69 \mathrm{~mm}$ mean shell length) in a $20 \mathrm{~m}$ flume (Butman \& Chapman 1989,
Trowbridge et al. 1989) made at 5 and $15 \mathrm{~cm} \mathrm{~s}^{-1}$ yielded an estimate of the vertical intercept $\left(z_{0}=0.169\right.$ $\mathrm{cm}, \mathrm{r}^{2}=0.99$ ) which was used to calibrate our estimation of the boundary layer profile within $0.5 \mathrm{~m}$ of the bed. The effects of form drag of mussel hummocks, and increased roughness due to larger roughness elements than the mussels themselves are not considered here.

A light-framed version of the ship-deployed Benthic Organic Seston Sampler (BOSS; Muschenheim et al. unpubl.) was used to take simultaneous water samples at 10 heights within $0.5 \mathrm{~m}$ of the bottom. Diver observation confirmed that the device operated properly, self-orienting into the current, and that the sampling trigger delay was sufficient to allow that any sediment resuspended upon deployment had sufficient time to be advected downstream before samples were taken. Single BOSS casts were taken both over the bed $(11 \mathrm{~m}$ downstream from the leading edge) and at a spot about 30 m upstream of the bed, within about 15 min of each other and account only for conditions at the time of sampling. Questions of time variation and patchiness were not addressed by our sampling technique. The individual syringe samples taken by the BOSS were subsampled for chl a, nitrogen and carbon analyses, as well as total suspended phytoplankton cells and species composition from $2 \mathrm{ml}$ settled counts of particles larger than $3 \mu \mathrm{m}$ in diameter. Chl a samples were performed in duplicate $(n=24)$ and the coefficient of variation was $9.9 \%$. The GFC carbon samples (120 to $200 \mathrm{ml}$ filtered) had a calibration coefficient of variation of $2.9 \%$ and filtration and sampling error were considered to be that of the chl a samples (about $10 \%$ ).

The combined flow and near-bed particle field data were used to construct vertical profiles of both volume flow and particle flux in the bottom $0.5 \mathrm{~m}$ of the water column. These profiles were compared to the experimental mussel pumping and filtration data, giving an estimate of the effective feeding zone of Mytilus edulis under the observed flow conditions (see Fig. 1)

\section{RESULTS AND DISCUSSION}

Pumping rates of Mytilus edulis at the sampling site averaged $9.8 \mathrm{l} \mathrm{h}^{-1} \mathrm{~g}^{-1}$. This is high when compared to earlier literature values but more recent work (Famme et al. 1986) has yielded values even higher. Since mussels are known to preferentially select phytoplankton from natural seston (Newell et al. 1989), filtration rates using chlorophyll as a tracer actually provide an estimate of pumping rate. While yielding rates up to $50 \%$ over rates determined using a Coulter Counter (where selected and non-selected particles are counted), the chlorophyll tracer method provides a more accurate means of assessing pumping rate in natural popula- 


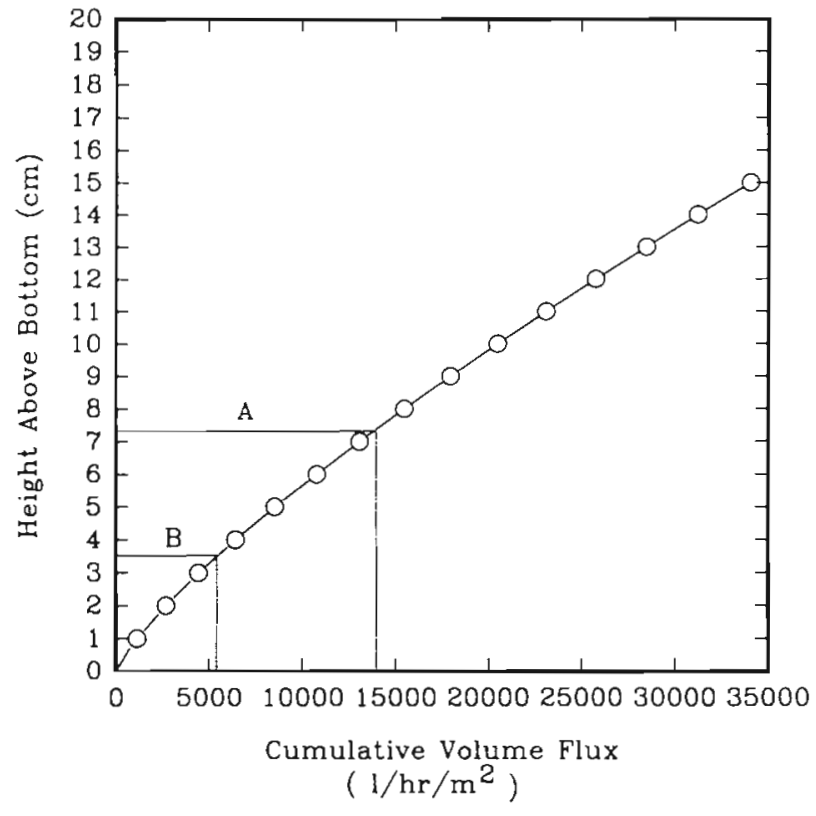

Fig. 1. Cumulative volume flux above mussel bed, calculated from BOSS samples of near-bed seston and S4 current meter data and calibrated with velocity distributions measured above a mussel bed in flume flow (Geyer \& Newell unpubl.). Region A represents hourly volume equivalent pumped by mussels. Region B represents hourly volume equivalent filtered if significant refiltration occurs (up to $35 \%$; Monismith et al. 1990)

tions. Using a mean selection coefficient of 1.51 (typical of mussels from Stonington, Maine; Table 4 in Newell et al. 1989), the observed filtration rate (on all particles) would be $6.51 \mathrm{~h}^{-1} \mathrm{~g}^{-1}$. The effects on the cal- culations would be that the mussels could filter about one-third less paticulate matter than as estimated below without consideration of selective feeding by Mytilus edulis.

Based on the hourly volume flow profile, estimated from the S4 measurements, the mussels were capable of pumping a volume equivalent to that flowing within 7 to $8 \mathrm{~cm}$ of the bed (Fig. 1). This estimation is dependent on the flow velocity and is really only appropriate to this particular site at the observed tidal stage. In fact it is quite likely that there is a significant amount of reprocessing and refiltering of water within just 2 or $3 \mathrm{~cm}$ of the bed. Monismith et al. (1990), using mechanical bivalve analogs in flume flows, have shown that the fraction of excurrent volume that gets recirculated through the incurrent siphon may be considerable (up to $35 \%$ in their experiments) and is strongly dependent on a bivalve's orientation to the axis of flow and to the magnitude of the flow.

Based on the feeding experiments, mean chlorophyll consumption of the experimental Mytilus edulis population was $20.7 \mu \mathrm{g}$ chl a $\mathrm{g}^{-1}$ dry wt (equivalent to $29 \mathrm{mg} \mathrm{chl} a \mathrm{~m}^{-2} \mathrm{~h}^{-1}$ ). This is well within the range of values observed in benthic ecosystem tunnels in The Netherlands (Dame \& Dankers 1988, Prins \& Smaal 1990). In addition, the differential between upstream and over-bed concentration profiles of suspended chlorophyll, total diatoms, benthic diatoms and total diatom cell volumes (Table 1, Fig. $2 \mathrm{~A}, \mathrm{~B}, \mathrm{C}$ ) shows a deficit in the 5 to $10 \mathrm{~cm}$ closest to the mussel bed. In contrast to the volume pumping results, the mussels accounted for barely $19 \%$ of the chlorophyll flux deficit in the bottom $8 \mathrm{~cm}$.

Table 1 Vertical profiles of chl a, carbon and nitrogen and diatom cell numbers both outside (upstream) and inside (directly over) the Stave Island mussel patch during ebb tide. Sampling heights of 'Surface' samples at the mussel bed and upstream stations were 291 and $319 \mathrm{~cm}$ respectively. Carbon and nitrogen data represent combined samples from 2 heights (e.g. 5 and $10 \mathrm{~cm}$ ) to provide enough sample volume for CHN analysis. Single sample volumes were sufficient for chl a analysis and cell counts

\begin{tabular}{|c|c|c|c|c|c|}
\hline $\begin{array}{l}\text { Height off bottom } \\
\text { of combined samples } \\
(\mathrm{cm})\end{array}$ & $\begin{array}{l}\text { Carbon } \\
\left(\mu \mathrm{g} \mathrm{l}^{-i}\right)\end{array}$ & $\begin{array}{c}\text { Nitrogen } \\
\left(\mu \mathrm{g}^{-1}\right)\end{array}$ & $\begin{array}{l}\text { Height off bottom } \\
\text { of single sample } \\
(\mathrm{cm})\end{array}$ & $\begin{array}{c}\text { Chl a } \\
\left(\mu \mathrm{gl}^{-1}\right)\end{array}$ & $\begin{array}{l}\text { Diatoms } \\
\text { (no. } \mathrm{ml}^{-1}\end{array}$ \\
\hline \multicolumn{6}{|c|}{ Upstream } \\
\hline 5 and 10 & 6471 & 907 & 5 & 7.1 & 811 \\
\hline 15 and 20 & 398 & 77 & 10 & 7.0 & 467 \\
\hline 25 and 30 & 434 & 65 & 15 & 5.5 & 450 \\
\hline 45 and 50 & 616 & 105 & 25 & 4.3 & 275 \\
\hline \multirow[t]{2}{*}{ Surface } & 883 & 134 & 45 & 4.9 & 219 \\
\hline & & & Surface & 15.8 & 223 \\
\hline \multicolumn{6}{|c|}{ Over mussel bed } \\
\hline 5 and 10 & 419 & 60 & 5 & 4.3 & 177 \\
\hline 15 and 20 & 354 & 59 & 10 & 4.2 & 191 \\
\hline 25 and 30 & 294 & 42 & 15 & 4.9 & 205 \\
\hline 45 and 50 & 301 & 52 & 25 & 4.3 & 136 \\
\hline \multirow[t]{2}{*}{ Surface } & 593 & 90 & 50 & 4.9 & 191 \\
\hline & & & Surface & 5.9 & 286 \\
\hline
\end{tabular}



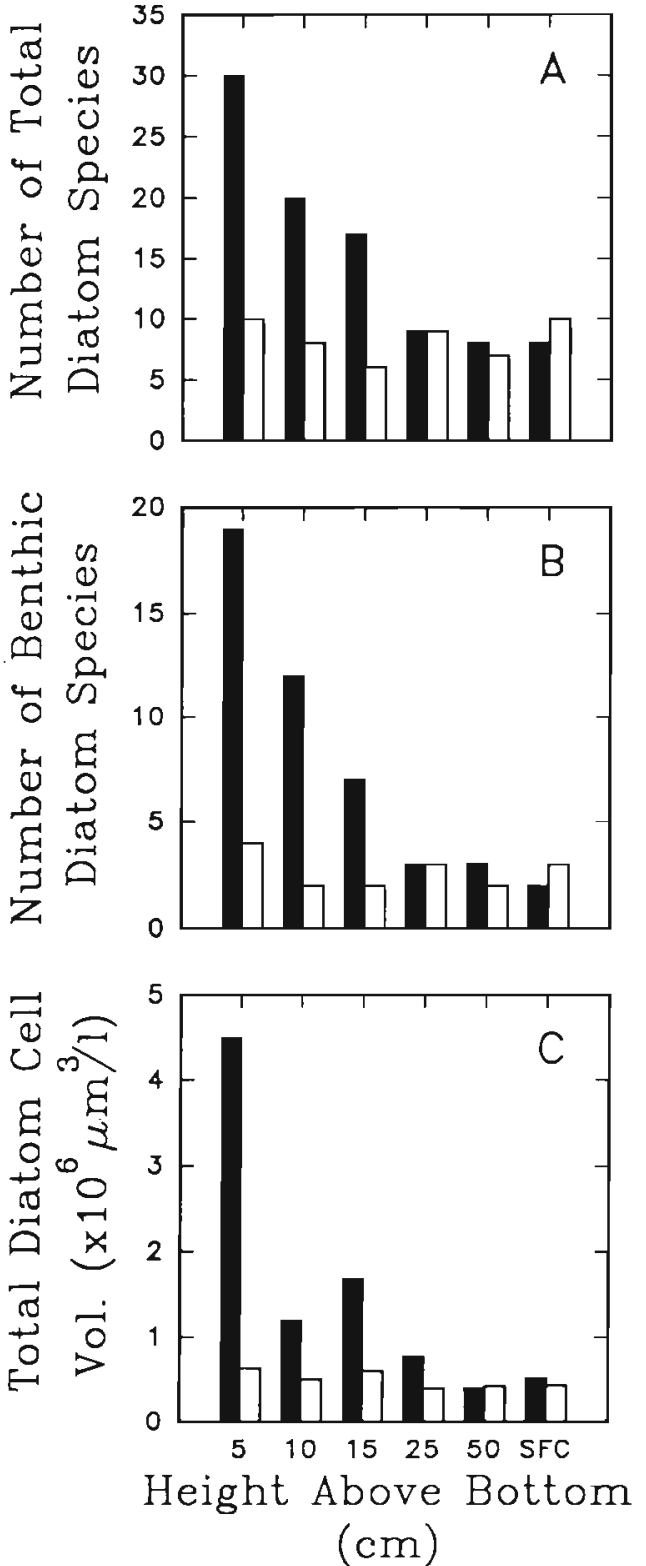

Fig. 2. Vertical distributions of (A) total number of diatom species; (B) number of benthic diatom species; and (C) total diatom cell volumes taken from BOSS samples at the experimental site. Solid bars: samples from $30 \mathrm{~m}$ upstream of the Mytilus edulis bed; open bars: samples taken $11 \mathrm{~m}$ downstream from the leading edge of a $22 \mathrm{~m}$ continuous mussel patch

The BOSS.samples of suspended particulate matter in the bottom $50 \mathrm{~cm}$ show distinct differences in particle concentration and composition between the upstream sample series and that over the mussel patch (Table 1). The upstream samples exhibited strong concentration gradients in all seston parameters measured, especially total carbon and phytoplankton cells (dominated by diatoms), with highest concentrations nearest the bed. Chlorophyll levels were elevated $\left(7 \mu \mathrm{g} \mathrm{l}^{-1}\right)$ in the 5 and $10 \mathrm{~cm}$ samples, falling to 4 to $4.5 \mu^{-1}$ at $50 \mathrm{~cm}$ above bottom. The high upstream chlorophyll concentration in the surface waters $\left(15.8 \mu \mathrm{g}^{-1}\right)$ was due to a localized patch of Mesodinium rubra, a phototactic ciliate which accounted for $65 \%$ of the biomass.

Over the mussel bed, chl a concentrations were quite uniform and on the order of $4 \mu \mathrm{g} \mathrm{l}^{-1}$. Total carbon and total cell numbers, having shown strong gradients in the upstream series, were reduced to lower levels and a more uniform profile over the patch. Within $5 \mathrm{~cm}$ of the upstream seabed, total carbon levels were more than an order of magnitude greater than over the mussels. Nitrogen concentration was also more uniform over the patch than upstream. There was no discernible pattern in the vertical profile of $\mathrm{C}: \mathrm{N}$ ratios. Measured carbon to phytoplankton carbon (based on cell volumes) ratios were ca $25: 1$ at $5 \mathrm{~cm}$ upstream of the bed, and 2:1 at the water surface. Thus, it appears that upstream detritus had strong vertical variation.

The pattern of total numbers of diatoms found in suspension between the 2 locations was similar to the chlorophyll, carbon and nitrogen results (Fig. 2). Of special interest is the species composition of suspended diatoms. Within $5 \mathrm{~cm}$ of the bed there were 3 times the number of diatom species, mostly benthic diatoms (Nitzschia spp. and Pleurosigma spp.) and larger pelagic species, and from 0 to $15 \mathrm{~cm}$ there were twice the number of diatom species found upstream of the patch as there were over it. More than $15 \mathrm{~cm}$ off the bed the diatom species numbers and composition were very similar both upstream and over the bed. This again points to removal by filtering Mytilus edulis as the primary agent and presents the possibility that mussels growing in the inner regions of a patch are exposed to a lessened level of food resource than those at the patch margins.

Analysis of the in situ feeding experiments combined with seston flux data may shed some light on the question of how to estimate the effective feeding zone of Mytilus edulis and other commercially important bivalves. The mussels are capable of pumping an hourly water volume equivalent to that passing within 7 to $8 \mathrm{~cm}$ off the bed (Fig. 1). If significant refiltration (up to a maximum of $35 \%$; Monismith et al. 1990) occurred, this value is reduced to approximately $3.5 \mathrm{~cm}$. Although the clearance rate experiments indicate that the mussels take only $20 \%$ of the observed seston flux deficit, there is evidence that they utilize a significant fraction of the suspended diatoms being advected from upstream. Large benthic diatoms (e.g. Gyrosigma balticum, Nitzschia spp.) which are prevalent in the 5 to $10 \mathrm{~cm}$ upstream samples are virtually absent over the 
patch. The upper water column diatoms changed little from upstream to over the patch and do not include the large benthic species. Newell et al. (1989) reported significant utilization of large benthic diatom species in $M$. edulis gut examinations. This strongly suggests that resuspended benthic diatoms are being removed by the mussels and not being mixed higher into the water column by increased turbulence over the patch. Mussels on the edge of a bottom patch therefore have both quantitatively and qualitatively different food resource availability than mussels further downstream, accounting at least in part for observed growth differences due to the 'edge effect' (Newell 1990).

Previous studies of the interactions of bivalve feeding currents with the ambient flow field have yielded varied results; perhaps a greater reflection of the diversity of species studied than of any underlying similarity of process. Ertman \& Jumars (1988) used dye traces to show that the infaunal cockle Clinocardium nuttallii only pulled water from the 1 to $2 \mathrm{~cm}$ directly above its siphons (although from 3 to $4 \mathrm{~cm}$ laterally) even in low ambient flow situations. Monismith et al. (1990) evidently saw an even greater lateral incurrent field as they concluded that fluid is drawn in at the height of the incurrent siphon above the bed, while the excurrent plume may extend several $\mathrm{cm}$ further up. In our results, the discrepancy between the feeding zone based on volume flux and that based on particle flux data strongly suggests that the effective feeding zone of the Mytilus edulis population is actually less than the $8 \mathrm{~cm}$ potential processing zone and is more likely restricted to within 3 to $4 \mathrm{~cm}$ of the incurrent siphon.

We note the difference in seston dynamics within mussel patches and at patch margins and the crucial role of patch size. Over the middle of a large patch, where a uniform vertical seston distribution may be established (and may be composed largely of nearly neutrally buoyant cells), turbulence is required to replenish the depleted zone near the bed to prevent food limitation. Whether the depletion occurred as the result of clearance by mussels at the patch margin or by particle trapping between roughness elements (mussel shells), the effect is the same to the inner patch mussels. At an upstream patch margin, there exist concentration and flux gradients which concentrate food particles (mostly heavier diatoms, which act like small sand grains in the flow; Muschenheim 1987a, b) near the bed and within reach of the mussels. In this situation, food limitation is unlikely. The resuspension of benthic diatoms and the settling of larger pelagic diatoms over a large area upstream of mussel beds may play an important role in the enhancement of growth at the outer patch margins.

Our calculations show that mussels may exhibit very high pumping rates and potentially are capable of completely processing the water flowing within 7 or $8 \mathrm{~cm}$ of the bed. That they only utilize $20 \%$ of the available seston flux within that region indicates that their effort is focussed within a narrower region closer to the bed and that a significant amount of re-processing occurs. The mussels may have access to particles farther from the bed than their estimated feeding zone, but it is not likely an overriding factor. Whether or not the estimate of the Mytilus edulis feeding zone is relevant to other bivalve species will require further investigation. Infaunal bivalves, such as Mya arenaria, Mercenaria mercenaria and others generally maintain their siphons at the level of the bed, whereas epifaunal species, exemplified by $M$. edulis, feed somewhat higher in the water column. Therefore, while an estimate of a 3 to $4 \mathrm{~cm}$ feeding zone may be appropriate for $M$. edulis at mid ebb-tide at this location, it does not necessarily hold for infaunal species exposed to different flow speeds. However the use of coordinated current and seston profiles, combined with feeding rate data, can do much to elucidate this important environmental variable.

Acknowledgements. We thank D. Johnson for expert boat handling aboard the FV 'Lively Lady' and D. Murphy for technical assistance in the field. Phytoplankton identifications were performed by $C$. Gregory and the CHN analyses were performed by $\mathrm{C}$. Garside, Bigelow Laboratory. The BOSS device was built by John Conrod in the Metrology shop, Bedford Institute of Oceanography. The manuscript was improved by comments from D. C. Gordon, B. T. Hargrave and P. D. Keizer, as well as from 3 anonymous reviewers. Funding for this project was provided by the National Science Foundation (under award number ISt8809760 to C.R.N.)

\section{LITERATURE CITED}

Butman, C. A., Chapman, R. J. (1989). The $17 \mathrm{~m}$ flume at the Coastal Research Laboratory. Part 1: Description and user's manual. Woods Hole Oceanogr. Inst. Tech. Rep. WHOI-89-10

Cahalan, J. A., Siddall, S. E., Luckenbach, M. W. (1989). Effects of flow velocity, food concentration and particle flux on growth rates of juvenile bay scallops, Argopecten irradians. J. exp. mar. Biol. Ecol. 129: 45-60

Dame, R. F., Dankers, N. (1988). Uptake and release of materials by a Wadden Sea mussel bed. J. exp. mar. Biol. Ecol. 118: $207-216$

Ertman, S. C., Jumars, P. A. (1988). Effects of bivalve siphonal currents on the settlement of inert particles and larvae. J. mar. Res 46: 797-813

Famme, P., Riisgård, H. U., Jørgensen, C. B. (1986). On direct measurements of pumping rates of the mussel Mytilus edulis. Mar. Biol. 92: 323-327

Frechette, M., Bourget, E. (1985a). Energy flow between the pelagic and benthic zones: factors controlling particulate organic matter available to an intertidal mussel bed. Can. J. Fish. Aquat. Sci. 42: 1158-1165

Frechette, M., Bourget, E. (1985b). Food-limited growth of Mytilus edulis L. in relation to the benthic boundary layer. Can. J. Fish. Aquat. Sci. 42: 1166-1170 
Frechette, M., Butman, C. A., Geyer, W. R. (1989). The importance of boundary-layer flows in supplying plankton to the benthic suspension feeder, Mytilus edulis L. Limnol. Oceanogr. 34: 19-36

Grizzle, R. E., Morin, P. J. (1989). Effect of tidal currents, seston, and bottom sediments on growth of Mercenaria mercenaria: results of a field experiment. Mar. Biol. 102: $85-93$

Grizzle, R. E., Lutz, R. A. (1989). A statistical model relating horizontal seston fluxes and bottom sediment characteristics to growth of Mercenaria mercenaria. Mar. Biol. 102: 95-105

Monismith, S. G., Koseff, J. R., Thompson, J. K., O'Riordan, K. A., Nepf, H. M. (1990). A study of model bivalve siphonal currents. Limnol. Oceanogr. 35: 680-696

Muschenheim, D. K. (1987a). The dynamics of near-bed seston flux and suspension-feeding benthos. J. mar. Res. 45: 473-496

Muschenheim, D. K. (1987b). The role of hydrodynamic sorting of seston in the nutrition of a benthic suspension feeder, Spio setosa (Polychaeta: Spionidae). Biol Oceanogr. 4: 265-287

Newell, C. R., Shumway, S. E. (1988). Development of a model to seed mussel bottom leases to their carrying capacity - Phase I results. Abstracts 1988 Annual Meeting. J. Shellfish Res. 7: 193

Newell, C. R., Shumway, S. E., Cucci T. L., Selvin, R. (1989). The effects of natural seston particle size and type on feeding rates, feeding selectivity and food resource avail-

This article was presented by G. C. Harding, Dartmouth, N.S., Canada ability for the mussel Mytilus edulis Linnaeus, 1758 at bottom culture sites in Maine. J. Shellfish Res. 8: $187-196$

Newell, C.R. 1990. The effects of mussel (Mytilus edulis, Linnaeus, 1758) position in seeded bottom patches on growth at subtidal lease sites in Maine. J. Shellfish Res. 9: 113-118

Nowell, A. R. M., Jumars, P. A. (1984). Flow environments of aquatic benthos. Ann. Rev. Ecol. Syst. 15: 303-328

Phinney, D. A., Yentsch, C. S. (1985). A novel phytoplankton chlorophyll technique: toward automated analysis. J. Plankton Res. 7: 633-642

Prins, T. C., Smaal, A. C. (1990). Benthic-pelagic coupling: the release of inorganic nutrients by an intertidal bed of $M Y$ tilus edulis. In: Barnes, M., Gibson, R. N. (eds.) Trophic relationships in the marine environment. Proc. 24th Eur. Mar. Biol. Symp. Aberdeen Univ. Press, Aberdeen, p. $89-103$

Riisgård, H. U., Mohlenberg, F. (1979). An improved automatic recording apparatus for determining the filtration rate of Mytilus edulis as a function of size and algal concentration. Mar. Biol. 52: 61-67

Trowbridge, J. H., Geyer, W. R., Butman, C. A., Chapman, R. J. (1989). The $17 \mathrm{~m}$ flume at the Coastal Research Laboratory. Part 2: Flow characteristics. Woods Hole Oceanogr. Inst. Tech. Rep. WHOI-89-11

Wildish, D. J., Kristmanson, D. D. (1979). Tidal energy and sublittoral macrobenthic animals in estuaries. J. Fish. Res. Bd Can. 36: 1197-1206

Manuscript first received: November 29, 1991

Revised version received: June 26, 1992 